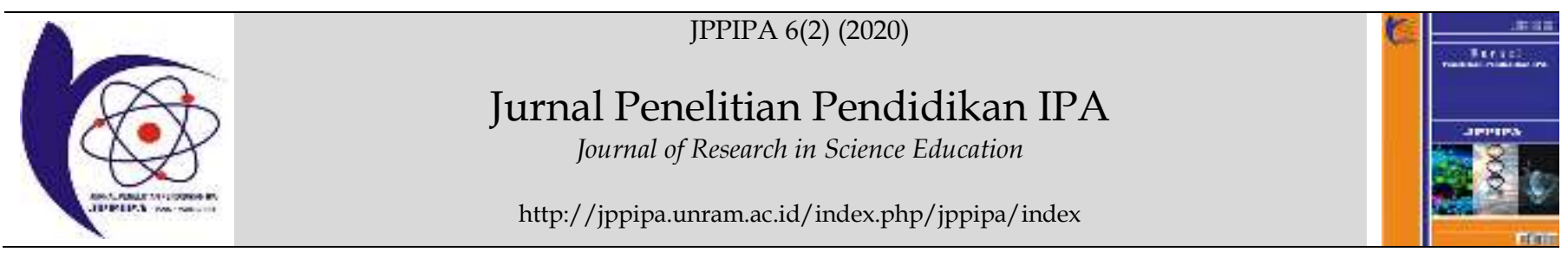

\title{
The validity of Physical Learning Device Based on Discovery Learning Model Assisted by Virtual Laboratory
}

\author{
Ni Wayan Riska Apriani ${ }^{*}$, Aris Doyan ${ }^{1,2}$, Nyoman Sridana $^{1,3}$, Susilawati $^{1,2}$ \\ ${ }^{1}$ Master of Science Education Program, University of Mataram, Lombok, West Nusa Tenggara, Indonesia. \\ ${ }^{2}$ Physics Education, Faculty of Teacher Training and Education, University of Mataram, Lombok, West Nusa Tenggara, Indonesia. \\ ${ }^{3}$ Mathematics Education, Faculty of Teacher Training and Education, University of Mataram, Lombok, West Nusa Tenggara, Indonesia.
}

DOI: https://doi.org/10.29303/jppipa.v6i2.264

\section{Article Info}

Received : January $15^{\text {th }}, 2020$

Revised : May 21 th, 2020

Accepted: May 24th, 2020

\begin{abstract}
The purpose of this study was to determine the validity of physics learning devices based on discovery learning models assisted by virtual laboratories. This type of research is research and development that refers to the 4-D development model. The 4-D development model consists of four steps namely, defining, designing, developing and disseminating. Learning tools developed in the form of syllabi, lesson plans, student worksheets, and evaluation instruments. This article only focuses on the process of testing the validity of learning tools by experts. The results of the analysis of the validity and reliability state the learning device is categorized as valid and can be used in physics learning.
\end{abstract}

Keywords: learning device; discovery learning; virtual laboratory; validity

Citation: Example: Apriana, N.W.R., Doyan, A., Sridana, N., \& Susilawati. (2020). The validity of Physical Learning Device Based on Discovery Learning Model Assisted by Virtual Laboratory. Jurnal Penelitian Pendidikan IPA (JPPIPA), 6(2), 132-135. doi: https:// doi.org/10.29303/jippipa.v6i2.264

\section{Introduction}

Learning devices are a means of support in the learning that is arranged for students and teachers (Tanjung et al, 2018). Next, Susdarwati et al, (2016) states that learning tools include student worksheets, lesson plans, and assessment sheets. Teachers must develop appropriate learning tools because this can support the success of the learning process (Wicaksono et al, 2017). Therefore, learning tools are an important thing, including in learning physics.

Physics is one part of science that studies various objects in nature, symptoms, and phenomena that occur in nature (Sari et al, 2017). Wicaksono, et al. (2017) states that physics is aimed at developing the ability to reason, think inductively, analytically and deductively in using the concepts and application of physics. Furthermore, the 2013 curriculum stated the purpose of learning physics is that students can master concepts and principles, have the skills and abilities to develop their knowledge to continue their education at a higher level (Kemendikbud, 2014). This is in line with the demands that must be had by students in the 21st century, namely communication, creativity and innovation, critical thinking, collaboration and problem-solving ability.

The results of field observations conducted by researchers at two high schools in Mataram found that students have low mastery of concepts and problemsolving abilities, the learning tools used have not guided students to be actively involved in learning. Also, the assessment instruments given have not yet tested the ability of problem solving and mastery of students' concepts. Therefore, researchers want to develop learning tools based on discovery learning models assisted by virtual laboratories, as one of the efforts to improve students' problem-solving abilities and mastery of concepts.

\footnotetext{
*Email: aprianiriska92@gmail.com
} 
The Discovery learning model is a learning model that guides students in finding concepts and discovering their concepts through discovery activities (Tumurun et al, 2016). Furthermore, Sari, et. al. (2017) states that discovery learning is a model that provides opportunities for students to find and find themselves. The Discovery model in its steps requires experimental activities, but not all experiments can be carried out significantly, so researchers provide alternative assistance in the form of virtual laboratories.

A virtual laboratory is a computer technology in the form of interactive multimedia that simulates laboratory experiments into computers (Agustine, et al., 2014). Sanggara \& Doyan, (2019) stated that a virtual laboratory is a media that is used to conduct experiments without using real experimental tools. Also, Baser \& Durmus, (2010) stated that experiments conducted virtually serve to provide constructive feedback to help students realize the application of their concepts, apply abstract concepts and encourage them to make improvements.

Based on these descriptions, researchers want to develop physics learning devices base on discovery learning models assisted by virtual laboratories that are valid for use in learning.

\section{Methode}

This research is included in the type of research and development (R\&D). The procedure used in the development of physics learning tools based on discovery learning models assisted by virtual laboratories refers to the $4 \mathrm{D}$ Thiagarajan and Sivasailam (1974) development steps namely define, design, develop, and disseminate. However, this research focuses on the development stage, namely the validity test. The learning device in the form of lesson plans, syllabus, student worksheets, concept mastery instruments and problem-solving ability instruments are validated using a validation sheet by three expert validators. Validation data were analyzed to find out the validity level using the equation:

$$
P=\frac{n}{N} x 100 \%
$$

$\mathrm{P}=$ average percentage

$\mathrm{n}=$ score obtained

$\mathrm{N}=$ maximum score

The validity level is determined by a Likert scale based on the following table.
Table 1: Validity Level

\begin{tabular}{ll}
\hline Range of average values $\%$ & Validity Level \\
\hline $0-20$ & Very invalid \\
$21-40$ & Invalid \\
$41-60$ & Valid enough \\
$61-80$ & Valid \\
$81-100$ & Very valid \\
\hline \multicolumn{1}{c}{ Arikunto (2010) }
\end{tabular}

The learning device is minimum at the valid category level to be used in learning. Next, to measure reliability, the results of the validity of the device are analyzed using a percentage agreement (Borich, 1994). Nasrah, et al., (2017) stated that the results of the device validation are declared to be reliable if the percentage agreement value $>75 \%$. The percentage agreement (PA) formula is as follows:

$$
P A=1-\frac{A-B}{A+B} \times 100 \%
$$

\section{PA: Percentage of agreement}

A: score assessment by experts who give high scores B: score assessment by experts who give low scores

Besides, advice from the three experts on each product development of learning tools is used as a material consideration to make revisions in product improvement.

\section{Result and Discussion}

The development of tools in the form of syllabus, lesson plans, student worksheets, concept mastery instruments, and problem-solving ability instruments disrupts the $4 \mathrm{D}$ development procedure which consists of four steps, the first step is defined. In this step, a final initial analysis is carried out to determine the character of students who will be the object of research. Students who will be studied are students of class X High School. The second stage designs, the activities carried out in this stage are determining the initial design of the learning tools to be developed. Learning tools that will be developed in the form of syllabus, lesson plans, student worksheets, and concept mastery instruments, and problem-solving ability instruments.

The third step is to develop, at the develop stage three activities are carried out namely the validation of the learning kit by three expert validators that produce draft I, then a limited trial with the results in the form of a draft II and finally a large-scale trial that will produce a final set. But in this study the researchers limited the validity of the learning device only. The validity of learning tools is obtained through assessment by three expert validators, validated learning devices in the form of lesson plans, syllabus, student worksheets and evaluation instruments. 
Learning devices developed are said to be valid if they meet valid criteria on content and constructs (Rochmad, 2012). The results of the validation analysis of the learning tools are shown in table 2.

Table 2. Learning Device Validation Results

\begin{tabular}{|c|c|c|c|}
\hline No & Aspect & $\begin{array}{l}\text { Percentage } \\
\text { Average \% }\end{array}$ & $\begin{array}{l}\text { Validity } \\
\text { Level }\end{array}$ \\
\hline 1 & Syllabus & $90 \%$ & Very Valid \\
\hline 2 & Lesson Plan & $82 \%$ & Very Valid \\
\hline 3 & Student Worksheets & $81 \%$ & Very Valid \\
\hline 4 & $\begin{array}{l}\text { The instrument of } \\
\text { Mastery of Concept }\end{array}$ & $80 \%$ & Valid \\
\hline 5 & $\begin{array}{l}\text { The instrument of } \\
\text { Problem-Solving } \\
\text { Ability }\end{array}$ & $80 \%$ & Valid \\
\hline
\end{tabular}

Based on the data displayed in the form of learning syllabus, learning plans and worksheets of students in the category is very valid because each device gets an average percentage of $90 \%$ for the syllabus, $82 \%$ of lesson plans, and $81 \%$ of students worksheets, then for the instrument of concept mastery and the instrument of problem-solving ability in the valid categories with the percentage of both is $80 \%$. In addition the reliability data from the validation analysis results are shown in Table 3.

Tabel 3. Reliability of Learning Tools Validation Results

\begin{tabular}{llll}
\hline No & Aspect & $\begin{array}{l}\text { Percentage } \\
\text { Agreement }\end{array}$ & Category \\
\hline 1 & Syllabus & $97 \%$ & Reliable \\
2 & Lesson Plan & $97 \%$ & Reliable \\
3 & Student Worksheets & $96 \%$ & Reliable \\
4 & $\begin{array}{l}\text { The instrument of } \\
\text { Concept Mastery } \\
5\end{array}$ & $95 \%$ & Reliable \\
$\begin{array}{l}\text { The instrument of } \\
\text { Problem-Solving } \\
\text { Ability }\end{array}$ & $94 \%$ & Reliable \\
\hline
\end{tabular}

Nasrah et al, (2017) stated that the results of the device validation are declared to be reliable if the percentage agreement value $>75 \%$. Based on these data the results of the validation of learning tools are said to be reliable because they have a PA value of syllabus and lesson plans of $97 \%$, student worksheets by $96 \%$, concept mastery instruments by $95 \%$, and problemsolving ability instruments by $94 \%$.

Suggestions and input submitted by the three validators for improvement in the syllabus that is adjusting the time allocation with learning activities to be carried out. Next for the lesson plans are the activities of students and teachers made more specific. After that on the part of the students' worksheets are made with language that is easily understood by students, for the instrument of concept mastery namely narrative questions made clearer so that it is easy to understand, as well as instruments for problem-solving ability, use effective language and reduce repetition of words.

\section{Conclusion}

Based on the results and discussion it can be concluded that the learning tools in the form of syllabus, lesson plans, student worksheets, concept mastery instruments, and problem-solving ability instruments that are developed are in the valid and reliable categories, besides that the suggestions from the validator can be used in improving the devices. Therefore, this learning tool can be used in learning

\section{Acknowledgements}

Thanks to the thesis supervisor who guided the research process so that it can be completed successfully. Thank you also transferred to the Science Study Program Master of Education, Postgraduate University of Mataram, which always facilitates the administration of this research process.

\section{References}

Agustine, D. Wiyono, K., dan Muslim, M. 2014. Pengembangan E-Learning Berbantuan Virtual Laboratory untuk Mata Kuliah Praktikum Fisika Dasar II. Program Studi Pendidikan Fisika FKIP UNSRI. Jurnal Inovasi dan Pembelajaran Fisika I (1): 33-42.

Arikunto, S. 2010. Manajemen Penelitian. Jakarta: Rineka Cipta

Baser, M., \& Durmus, S. 2010. The Effectiveness Of Computer Supported Versus Real Laboratory Inquiry Learning Environments On The Understanding Of Direct Current Electricity Among Pre-Service Elementary School Teachers. Eurasia Journal of Mathematics, Science $\mathcal{E}$ Technology Education, 6(1): 47-61.

Borich, G. D. 1994. Observation skills for effective teaching. New York.

Kemendikbud. (2014). Materi Pelatihan Implementasi Kurikulum 2013 tahun ajaran 2014. Mata Pelajaran Fisika SMA/SMK. Jakarta: Kemendikbud

Nasrah, N., Jasruddin, J., \& Tawil, M. 2017. Pengembangan Perangkat Pembelajaran Fisika Berbasis Pendekatan Contexstual Teaching And Learning (CTL) Untuk Memotivasi Dan Meningkatkan Hasil Belajar Fisika Peserta Didik Kelas VIII SMP Negeri 1 Balocci Pangkep. Jurnal Pendidikan Fisika-Journal of Physics Education, 5(2), 235-248. doi: 10.26618/jpf.v5i2.709

Sari, P. I., Gunawan, G., \& Harjono, A. (2017). Penggunaan Discovery Learning Berbantuan 
Laboratorium Virtual pada Penguasaan Konsep Fisika Siswa. Jurnal Pendidikan Fisika dan Teknologi, 2(4), 176-182.

Rochmad. (2012). Desain Model Pengembangan Perangkat Pembelajaran Matematika. Jurnal Keano, 3(1), 59-72.

Sanggara, P. W., \& Doyan, A. (2019). The effect of Process Oriented Guided Inquiry Learning Model Based on Virtual Laboratory toward Problem Solving abilities of Physics Student. Jurnal Penelitian Pendidikan IPA, 5(1).doi: 10.29303/jppipa.v5i1.154

Susdarwati, Saranto \& Cari. (2016). Pengembangan Perangkat Pembelajaran Fisika Berbasis Problem Based Learning (PBL) Pada Materi Hukum Newton Dan Penerapannya Kelas X SMAN 2 Mejayan. Jurnal Inkuiri, 5(3), 1-11. doi: $\underline{10.20961 / \text { inkuiri.v5i3.9434 }}$

Tanjung, H. S., \& Nababan, S. A. (2018). Pengembangan Perangkat Pembelajaran Matematika Berorientasi Model Pembelajarn Berbasis Masalah (PBM) Untuk Meningkatkan Kemampuan Berpikir Kritis Siswa SMA seKuala Nagan Raya Aceh. Genta Mulia: Jurnal Ilmiah Pendidikan, 9(2).

Thiagarajan \& Sivasailam. 1974. Instructional Development for Training Teachers of Exceptional Children: A Sourcebook. Indiana: Indiana University.

Tumurun, S. W., Gusrayani, D., \& Jayadinata, A. K. (2016). Pengaruh Model Pembelajaran Discovery Learning terhadap Keterampilan Berpikir Kreatif Siswa pada Materi Sifat-Sifat Cahaya. Jurnal Pena Ilmiah, 1(1), 101-110.doi: 10.23819/pi.v1i1.2936

Wicaksono, I., Jatmiko, B., \& Prastowo, T. (2017). Pengembangan Perangkat Pembelajaran Fisika Model Learning Cycle 5E untuk Meningkatkan Pemahaman Konsep Siswa pada Materi Fluida Statis. JPPS (Jurnal Penelitian Pendidikan Sains), 4(2), 518-524. doi: $\underline{10.26740 / j p p s . v 4 n 2 . p 518-524}$ 